https://doi.org/10.52288/bp.27089851.2020.12.08

\title{
Research on the Impact of Takeout Platform's Electronic Service Quality on Customer Loyalty
}

\author{
Ju-Xiang Zhang ${ }^{1 *} \quad$ Hui-Jie Sun ${ }^{2}$
}

\begin{abstract}
This paper analyzed the influence of electronic service quality of takeout platform on customer loyalty. The results showed that the ease of use, food safety, performance, privacy, interactivity, compensation and diversity of service quality of takeaway platform had a positive impact on customer loyalty. Customer satisfaction played an intermediary role between electronic service quality and customer loyalty. Based on the results, this paper put forward some advices such as improving delivery speed, improving the safety quality, protecting user information security, expanding service categories, and improving operational efficiency to enhance service quality as well as customer loyalty.
\end{abstract}

Keywords: Customer Satisfaction, Customer Loyalty, Takeout Platform, Electronic Service Quality

\section{Introduction}

With the steady development of Chinese economy and the emerging network platform, a large number of consumers order meals online. Consumers pay more and more attention to the service quality of takeout platform when choosing products Service quality become a key factor in the competition for platforms. It is necessary to improve the service quality according to the needs of customers, so as to enhance customer satisfaction and loyalty

\section{Literature Review}

\subsection{Electronic Service Quality}

The definition of electronic service quality was first proposed by Parasuraman et al. (2005), the famous service quality management experts in the United States. They believed that the E-service quality reflects the convenience of effective shopping, purchasing and shipping of a website. Águila-Obra et al. (2013) also gave a general definition of e-service, that is, E-service is a web service, which is managed by customers and has natural interaction. In this paper, the service quality is defined as the degree to which the platform provides tangible or intangible services to meet the customers' ideal expectations.

Parasuraman et al. (2005) designed an E-S-QUAL scale on the basis of SERVQUAL Model. The E-S-Qual scale, also known as the core quality of service scale, covers four dimensions: information availability and internal ease of use or availability, privacy security and performance, as shown in Table 1.

\footnotetext{
${ }^{1}$ Associate Professor of School of Management, Xiamen University Tan Kah Kee College, 14827686

@qq.com*corresponding author

2 School of Management, Xiamen University Tan Kah Kee College
} 
Table 1. E-S-Qual scale

\begin{tabular}{|c|c|}
\hline Dimension & Items \\
\hline Efficiency & $\begin{array}{l}\text { EFF1 This site makes it easy to find what I need. } \\
\text { EFF2 It makes it easy to get anywhere on the site. } \\
\text { EFF3 It enables me to complete a transaction quickly. } \\
\text { EFF4 Information at this site is well organized. } \\
\text { EFF5 It loads its pages fast. } \\
\text { EFF6 This site is simple fast. } \\
\text { EFF7 This site enables me to get on to it quickly. } \\
\text { EFF8 This site is well organized, }\end{array}$ \\
\hline System Availability & $\begin{array}{l}\text { SYS1 This site is always available for business. } \\
\text { SYS2 This site launches and runs right away. } \\
\text { SYS3 This site dose not crash. } \\
\text { SYS4 Pages at this site do not freeze after I enter my order } \\
\text { information. }\end{array}$ \\
\hline Fulfillment & $\begin{array}{l}\text { FUL1 It delivers orders when promised. } \\
\text { FUL2 This site makes items available for deliver within a suitable } \\
\text { time frame. } \\
\text { FUL3 It quickly delivers what I order. } \\
\text { FUL4 It sends out the its ordered. } \\
\text { FUL5 It has in stock the items the company claims to have. } \\
\text { FUL6 It is truthful about its offerings. } \\
\text { FUL7 It makes accurate promises about delivery of products. }\end{array}$ \\
\hline Privacy & $\begin{array}{l}\text { PRI1 It protects information about my Web-shopping behavior. } \\
\text { PRI2 It does not share my personal information with other sites. } \\
\text { PRI3 This site protects information about my credit card. }\end{array}$ \\
\hline
\end{tabular}

Source: Parasuraman et al. (2005)

\subsection{Customer Loyalty}

Loyalty is a psychological term at first. After the concept was introduced into the field of marketing, scholars have gradually studied "customer loyalty". Newman \& Werbel (1973) defined customer loyalty as that consumers buy a certain brand of goods directly while shopping, and no longer look for other information. It represents that consumers have a certain tendency to purchase the same brand products and service. Lam (2003) believes that customer loyalty is the commitment of consumers to businesses. Even if there are more choices, consumers will not change their previous choices. Li (2004) defined customer loyalty as the behavior that consumers repeatedly purchase based on their trust in a brand, and maintain the brand when it has problems.

Based on the views of the above scholars, this paper defines consumer loyalty from the perspective of attitude and behavior. Attitude loyalty refers to the psychological dependence and recognition of consumers for a certain product or service while behavioral loyalty refers to the behavior that consumers purchase and use again based on psychological level. This behavior includes repeated purchase and use of products and services of the same brand, loyalty after more choices, recommendation of the brand to the surrounding people, etc.

\subsection{The Relationship of Electronic Service Quality and Customer Loyalty}

In recent years, academia began to study the relationship between e-service quality and customer loyalty. Deng et al. (2014) studied the impact of logistics service quality on 
customer loyalty under the network environment, and found that customer satisfaction plays an intermediary role between them. Logistics service quality indirectly affects the accumulation of customer loyalty through customer satisfaction, which has important reference value. Zhao et al. (2015) divided the service quality of takeaway O2O into the service quality of takeaway websites and the service quality of takeout merchants. The results showed that customer satisfaction plays a completely mediating role in the relationship between service quality and customer loyalty. In addition, the service quality of takeaway websites has a greater impact on customer satisfaction than that of takeaway merchants. Chen \& Lei (2017) used structural equation model to explore the influencing factors and mechanism of customer loyalty of takeaway $\mathrm{O} 2 \mathrm{O}$ platform. The results exhibited that customer trust can directly affect customer loyalty; customer trust, online platform characteristics and offline service quality all indirectly affect customer loyalty with customer satisfaction as intermediary variable, and customer satisfaction and switching cost are the main influencing factors of customer loyalty on takeaway $\mathrm{O} 2 \mathrm{O}$ platform. Through empirical research, Wang \& Liu (2018) found that the assurance, responsiveness, and tangibility of service quality of takeout platform have a direct positive impact on customer satisfaction, and have an indirect positive impact on continuous use through customer satisfaction. The reliability and responsiveness of service quality have no significant impact on customer satisfaction, but have a direct positive impact on continuous use. Empathy has no significant effect on customer satisfaction and continuous use. Yin \& Gao (2020) demonstrated that the timeliness, convenience, safety, and reliability of delivery service significantly affect the functional value and hedonic value of users, and then affect the satisfaction of users. The research results play an important role in improving the delivery service quality and customer satisfaction.

\section{Research Model and Hypotheses}

\subsection{Model Building}

Basis on the E-S-Qual scale and the viewpoints of scholars Chen \& Lei (2017) and Yin $\&$ Gao (2020), a model for takeout platform electronic service quality is built as shown in Figure 1.

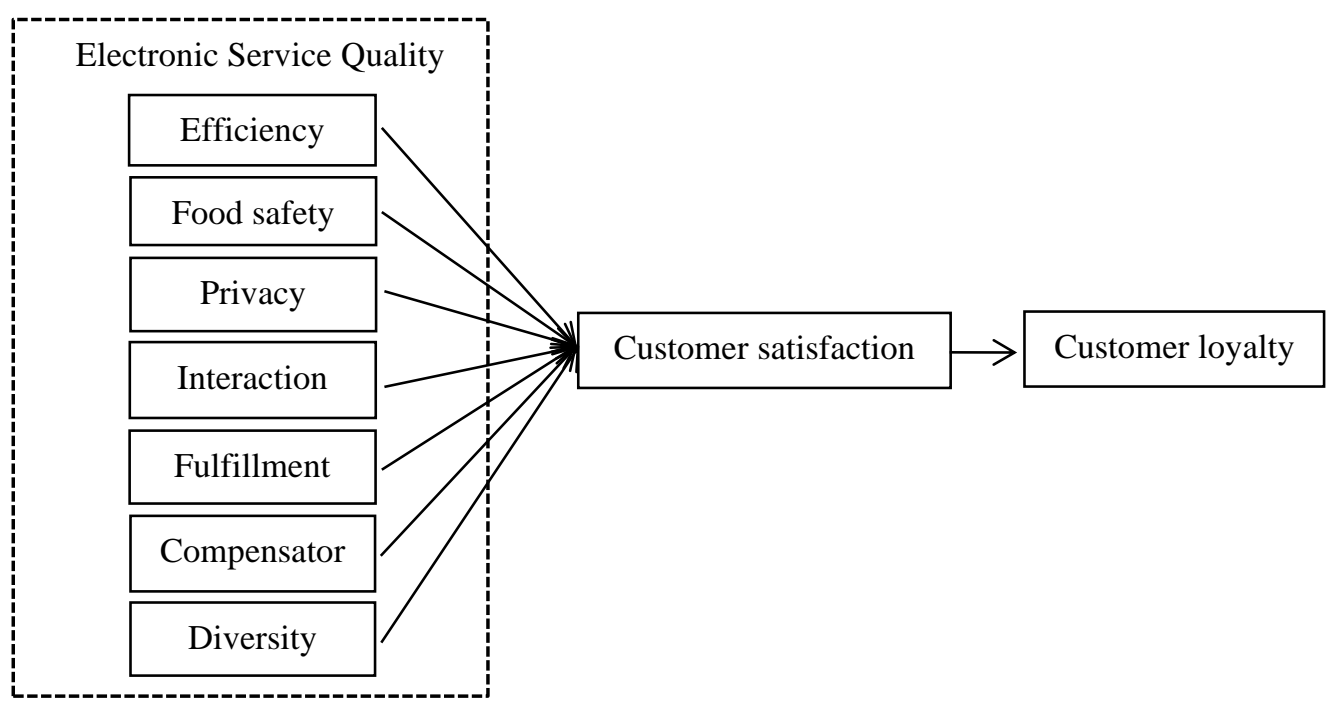

Figure 1. Takeout platform electronic service quality model 


\subsection{Research Hypothesis}

The following is the research hypothesis based on references, as shown in Table 2.

Table 2. Research hypothesis

\begin{tabular}{ll}
\hline No. & \multicolumn{1}{c}{ Research hypothesis } \\
\hline H1 & Ease of use has a significant positive effect on customer satisfaction \\
H2 & Food safety has a significant positive effect on customer satisfaction \\
H3 & Privacy has a significant positive effect on customer satisfaction \\
H4 & Interaction has a significant positive effect on customer satisfaction \\
H5 & Fulfillment has a significant positive effect on customer satisfaction \\
H6 & Compensatory has a significant positive effect on customer satisfaction \\
H7 & Diversity has a significant positive effect on customer satisfaction \\
H8 & Customer satisfaction has a significant positive effect on customer loyalty \\
H9 & The service quality of the takeout platform has a significant positive effect on \\
& customer loyalty \\
\hline
\end{tabular}

\section{The Empirical Research}

\subsection{Descriptive Analysis of the Sample}

In this study, 350 questionnaires were collected. Among them, 311 questionnaires are valid and the effective rate was $88.9 \%$. There were 160 female interviewees in the questionnaire survey, accounting for $51.4 \%$, and male interviewees occupied $48.6 \%$. The distribution of male and female is relatively average. The monthly income of the interviewees was between RMB2,000 to RMB5,999. The majority of the interviewees who use the takeaway service are 18-30 years old, accounting for $52.4 \%$. The frequency of placing orders on takeout platforms was mostly "several times a week", with a total of $46.9 \%$.

\subsection{Reliability Analysis}

The overall reliability test of the data for the survey is shown in Table 3 using SPSS22.0. The Cronbach's Alpha coefficient is 0.956 , which is over 0.9 and means the overall data has a higher reliability.

Table 3. Reliability statistics

\begin{tabular}{cc}
\hline Cronbach's Alpha & Number of Items \\
\hline .956 & 39 \\
\hline
\end{tabular}

\subsection{Validity Analysis}

As shown in Table 4, the KMO score of the collected data is above 0.9 , which indicates that the validity of the variable is very high. The significance is 0.000 , less than 0.01 , indicating that the result is very significant. Therefore, this data is very suitable for factor analysis.

\subsection{Factor Analysis}

In this study, seven independent variables were analyzed by principal component analysis, and seven factors with initial eigenvalue greater than 1 were extracted and named as ease of use, food safety, performance, privacy, interaction, compensation, and diversity. 
The maximum variance method is used to rotate the factor load matrix orthogonally, and the cumulative interpretation variance rate is $63.432 \%$, more than $60 \%$. It shows that the seven factors can reflect most of the information, and it is appropriate to extract the seven factors.

Table 4. KMO and Bartlett's Test

\begin{tabular}{lcc}
\hline \multicolumn{2}{c}{ Kaiser-Meyer-Olkin Measure of Sampling Adequacy } & .935 \\
\hline \multirow{3}{*}{ Bartlett's Test of Sphericity } & Approx. Chi-Square & $6,819.408$ \\
& df & 741 \\
& Sig. & .000 \\
\hline
\end{tabular}

\subsection{Regression Analysis}

\subsubsection{Takeout Platform Service Quality to Regression Analysis of Customer Satisfaction}

As shown in Table 5, $\mathrm{R}^{2}$ represents the degree of interpretation of the regression equation to the dependent variable, and the adjusted $\mathrm{R}^{2}$ is 0.770 , indicating that the fitting equation can explain the change of the dependent variable $77 \%$.

Table 5. Model summary

\begin{tabular}{|c|c|c|c|c|c|c|c|c|c|}
\hline \multirow{3}{*}{ Model } & \multirow[b]{2}{*}{$\mathrm{R}$} & \multirow{2}{*}{$\mathrm{R}^{2}$} & \multirow{2}{*}{$\begin{array}{c}\text { Adjusted } \\
\mathrm{R}^{2}\end{array}$} & \multirow{2}{*}{$\begin{array}{l}\text { Std. Error of } \\
\text { the Estimate }\end{array}$} & \multicolumn{5}{|c|}{ Change Statistics } \\
\hline & & & & & $\mathrm{R}^{2}$ Change & F Change & df1 & $\mathrm{df} 2$ & Sig. F Change \\
\hline & $.880^{\mathrm{a}}$ & .775 & .770 & .29499 & .775 & 148.946 & 7 & 303 & .000 \\
\hline
\end{tabular}

a. Predictors: Ease of use, Food safety, Privacy, Interaction, Fulfillment, Compensatory, Diversity

Through the analysis in Table 6 , the significance of each dimension is less than 0.05 , indicating that it has a significant positive impact on customer satisfaction. From the regression coefficient, safety and compensation have the greatest impact on customer satisfaction. The regression equation is as follows which indicates food safety and privacy have great influence on customer loyalty.

Customer satisfaction $=-0.886+0.097 \times$ Ease of use $+0.331 \times$ Privacy $+0.272 \times$ Food safety $+0.104 \times$ Fulfillment $+0.106 \times$ Interaction $+0.157 \times$ Compensatory $+0.162 \times$ Diversity

Table 6. Coefficients ${ }^{\mathrm{a}}$

\begin{tabular}{|c|c|c|c|c|c|c|}
\hline & \multirow[t]{2}{*}{ Model } & \multicolumn{2}{|c|}{ Unstandardized Coefficients } & \multirow{2}{*}{$\begin{array}{c}\begin{array}{c}\text { Standardized } \\
\text { Coefficients }\end{array} \\
\text { Beta } \\
\end{array}$} & \multirow[t]{2}{*}{$\mathrm{t}$} & \multirow[t]{2}{*}{ Sig. } \\
\hline & & $\mathrm{B}$ & Std. Error & & & \\
\hline \multirow{8}{*}{1} & (Constant) & -.886 & .143 & & -6.207 & .000 \\
\hline & Ease of use & .097 & .045 & .086 & 2.149 & .032 \\
\hline & Privacy & .331 & .045 & .289 & 7.348 & .000 \\
\hline & Food safety & .272 & .038 & .235 & 7.065 & .000 \\
\hline & Fulfillment & .104 & .044 & .092 & 2.360 & .019 \\
\hline & Interaction & .106 & .041 & .098 & 2.611 & .009 \\
\hline & Compensatory & .157 & .037 & .168 & 4.259 & .000 \\
\hline & Diversity & .162 & .041 & .164 & 3.976 & .000 \\
\hline
\end{tabular}




\subsubsection{Regression Analysis of Customer Satisfaction to Customer Loyalty}

As shown in Table 7, the adjusted $\mathrm{R}^{2}$ is 0.708 which indicates that the fitting equation can explain the change of $70.8 \%$ in the dependent variable. According to Table 8 , there is a significant correlation between customer satisfaction and customer loyalty. The regression equation is as follows:

Customer loyalty $=0.816+0.763 \times$ Customer satisfaction

Table 7. Model summary

\begin{tabular}{|c|c|c|c|c|c|c|c|c|c|}
\hline \multirow[b]{2}{*}{ Model } & \multirow[b]{2}{*}{$\mathrm{R}$} & \multirow{2}{*}{$\mathrm{R}^{2}$} & \multirow{2}{*}{$\begin{array}{c}\text { Adjusted } \\
\mathrm{R}^{2}\end{array}$} & \multirow{2}{*}{$\begin{array}{l}\text { Std. Error of } \\
\text { the Estimate }\end{array}$} & \multicolumn{5}{|c|}{ Change Statistics } \\
\hline & & & & & $\mathrm{R}^{2}$ Change & F Change & $\mathrm{df1}$ & $\mathrm{df} 2$ & Sig. F Change \\
\hline & $.842^{\mathrm{a}}$ & .709 & .708 & .30053 & .709 & 753.784 & 1 & 309 & .000 \\
\hline
\end{tabular}

a. Predictors: (Constant), Customer satisfaction

Table 8. Coefficients ${ }^{\mathrm{a}}$

\begin{tabular}{|c|c|c|c|c|c|}
\hline \multirow[t]{2}{*}{ Model } & \multicolumn{2}{|c|}{ Unstandardized Coefficients } & $\begin{array}{c}\text { Standardized } \\
\text { Coefficients }\end{array}$ & \multirow[t]{2}{*}{$\mathrm{t}$} & \multirow[t]{2}{*}{ Sig. } \\
\hline & $\mathrm{B}$ & Std. Error & Beta & & \\
\hline (Constant) & .816 & .099 & & 8.220 & .000 \\
\hline $\begin{array}{c}\text { Customer } \\
\text { satisfaction }\end{array}$ & .763 & .028 & .842 & 27.455 & .000 \\
\hline
\end{tabular}

\subsubsection{Regression Analysis of Takeout Platform Service Quality to Customer Loyalty}

According to Table 9 , the adjusted $\mathrm{R}^{2}$ is 0.754 , indicating that the fitting equation can explain the change $75.4 \%$ of the dependent variable, the overall fitting degree is good.

Table 9. Model Summary

\begin{tabular}{|c|c|c|c|c|c|c|c|c|c|}
\hline \multirow{3}{*}{ Model } & \multirow{2}{*}{$\mathrm{R}$} & \multirow{2}{*}{$\mathrm{R}^{2}$} & \multirow{2}{*}{$\begin{array}{c}\text { Adjusted } \\
\mathrm{R}^{2}\end{array}$} & \multirow{2}{*}{$\begin{array}{l}\text { Std. Error of } \\
\text { the Estimate }\end{array}$} & \multicolumn{5}{|c|}{ Change Statistics } \\
\hline & & & & & $\mathrm{R}^{2}$ Change & F Change & df1 & $\mathrm{df} 2$ & Sig. F Change \\
\hline & $.871^{\mathrm{a}}$ & .759 & .754 & .27621 & .759 & 136.451 & 7 & 303 & .000 \\
\hline
\end{tabular}

a. Predictors: (Constant), Ease of use, Food safety, Privacy, Interaction, Fulfillment, Compensatory, Diversity

As demonstrated in Table 10, the regression coefficients of ease of use, privacy, food safety, performance, interaction, and compensation are all above 0.1 , and the significance level is less than 0.05 , indicating that it has a significant positive impact on customer loyalty. The significance of diversity variables was 0.178 , greater than 0.05 , indicating that the linear relationship between diversity and explained variables was not significant. However, it does not mean that diversity has nothing to do with customer loyalty. It may be that consumers will ignore the importance of diversity and weaken their demand when they already have rich categories of takeaway platforms. The regression equation is summarized as follows:

Customer loyalty $=-0.772+0.228 \times$ Ease of use $+0.175 \times$ Privacy $+0.376 \times$ Food safety $+0.228 \times$ Fulfillment $+0.170 \times$ Interaction $+0.161 \times$ Compensatory 
Table 10. Coefficients ${ }^{\mathrm{a}}$

\begin{tabular}{ccccccc}
\hline \multirow{2}{*}{ Model } & \multicolumn{2}{c}{ Unstandardized Coefficients } & \multicolumn{2}{c}{$\begin{array}{c}\text { Standardized } \\
\text { Coefficients }\end{array}$} & \multirow{2}{*}{$\mathrm{t}$} & Sig. \\
\cline { 2 - 4 } & $\mathrm{B}$ & Std. Error & Beta & & \\
\hline \multirow{2}{*}{ (Constant) } & -.772 & .134 & & -5.680 & .000 \\
& .228 & .042 & .224 & 5.421 & .000 \\
Ease of use & .175 & .042 & .181 & 4.672 & .000 \\
& Privacy & .376 & .036 & .359 & 10.439 & .000 \\
1 & Food safety & .228 & .041 & .223 & 5.562 & .000 \\
& Fulfillment & .170 & .038 & .174 & 4.465 & .000 \\
& Interaction & .161 & .039 & .154 & 3.876 & .000 \\
& Compensatory & .047 & .034 & .055 & 1.349 & .178 \\
\hline a. Dependent Variable: Customer loyalty & & & &
\end{tabular}

\subsection{Intermediary Role of Customer Satisfaction}

Customer satisfaction for the intermediary role between service quality and customer loyalty have been studied and verified by many scholars, so this article analyzes the customer satisfaction of the intermediary role as well. The results are shown in Table 11. When customer satisfaction is put in, privacy, compensatory and diversity fail to enter the regression equation. It shows that customer satisfaction plays a mediation role completely in their impact on customer loyalty. Other variables, such as ease of use decreased from 0.228 to 0.188 , food safety decreased from 0.376 to 0.262 , fulfillment decreased from 0.228 to 0.185 , and interactive decreased from 0.170 to 0.125 , play partial intermediary role in the customer satisfaction.

Table 11. Intermediary role of customer satisfaction

\begin{tabular}{ccccccc}
\hline & \multicolumn{3}{c}{ Model 1 } & \multicolumn{3}{c}{ Model 2 } \\
\cline { 2 - 7 } & $\mathrm{B}$ & $\mathrm{t}$ & $\mathrm{Sig}$. & $\mathrm{B}$ & $\mathrm{t}$ & Sig. \\
\hline Ease of use & .228 & 5.421 & .000 & .188 & 4.942 & .000 \\
Privacy & .175 & 4.672 & .000 & - & - & - \\
Food safety & .376 & 10.439 & .000 & .262 & 7.522 & .000 \\
Fulfillment & .228 & 5.562 & .000 & .185 & 4.985 & .000 \\
Interaction & .170 & 4.465 & .000 & .125 & 3.637 & .000 \\
Compensatory & .161 & 3.876 & .000 & - & - & - \\
Diversity & - & - & - & - & - & - \\
Customer & - & - & - & .421 & 8.746 & .000 \\
satisfaction & - & & & & & \\
\hline
\end{tabular}

\subsection{Hypothesis Testing}

From the above analysis, the following conclusions are obtained as shown in Table 12.

Table 12. Research conclusion

\begin{tabular}{ccc}
\hline No. & \multicolumn{1}{c}{ Research hypothesis } & $\begin{array}{c}\text { verification } \\
\text { results }\end{array}$ \\
\hline H1 & Ease of use has a significant positive effect on customer satisfaction & Support \\
H2 & Food safety has a significant positive effect on customer satisfaction & Support \\
H3 & Privacy has a significant positive effect on customer satisfaction & Support
\end{tabular}


H4 Interaction has a significant positive effect on customer satisfaction

H5 Fulfillment has a significant positive effect on customer satisfaction

H6 Compensatory has a significant positive effect on customer satisfaction

H7 Diversity has a significant positive effect on customer satisfaction

H8 Customer satisfaction has a significant positive effect on customer loyalty

\section{Suggestions for Improving Customer Loyalty on Takeout Platform}

\subsection{Improving Delivery Speed}

Distribution speed is one of the key factors affecting user dining experience. The delivery platform explores the perfect logistics mode platform, improves the logistics technology level, and promotes the distribution of the logistics distribution order and the choice of the intelligent route, which is the basis for the promotion of competitiveness. The successful logistics system itself is of great value, and the delivery platform will greatly reduce the cost of entry into other services O2O. Distribution logistics and food safety are two key factors to improve service quality.

\subsection{Improving the Safety of Takeout Food}

Food safety is a big demand for the takeout platform. In order to ensure the food safety, it is necessary to strengthen the audit of the merchants' entry, so as to reduce the possibility of problems from the source. Moreover, platforms need to establish information sharing mechanism. Through sharing information of illegal merchants, the whole industry can reduce the food safety risks together and improve the service quality. In addition, industry associations should strengthen the supervision of platforms. We should not only pay attention to the handling of problems, but also control the quality of merchants, so as to reduce the possibility of problems from the source.

\subsection{Protecting User Information Security}

The takeout platform should strengthen the protection of consumers. Each platform should set up "Privacy-protection" function to protect customers' information security. Through this function, the customer's real mobile phone number is hidden. Merchants and delivery personnel contact customers through the virtual number provided by takeout platforms. Therefore, customers' privacy disclosure and harassment are avoided to a lager degree. The function of "Privacy-protection" establishes a security barrier for customers, and enables them to obtain a safe and trusted consumption experience.

\subsection{Expanding Service Categories}

The delivery platform should actively expand the distribution categories. Through investment and alliance, the platform cooperates with supermarkets, shopping malls and other types of businesses. In addition to food distribution, platforms can increase the distribution of fresh food, medicine, flowers and other categories. By making full use of the advantages of logistics, takeout platforms can effectively upgrade from a single vertical business to a comprehensive business platform, thus increasing consumer viscosity and improving service quality. Platforms should also pay attention to enterprise users and expand the distribution service of multiple products according to the characteristics of the working population. 


\subsection{Improving the Operational Efficiency of the Platform}

As the basic information service of the delivery platform, location-based services (LBS) is indispensable and can effectively shorten the delivery time and cost. With the use of LBS, the delivery platform can accurately display the outside suppliers. In addition, the takeout platform can analyze the needs of consumers through big data and better understand customers. Accurate marketing based on the analysis results to help merchants promote products. It is suggested that more artificial intelligence should be added to the online delivery service system, such as intelligent delivery vehicle and intelligent central kitchen.

\section{Conclusion}

From the research results, ease of use, food safety, fulfillment and privacy have a greater impact on customer loyalty, while the impact of compensation and interaction is relatively small. However, food safety and privacy have great influence on customer satisfaction.

\section{References}

1. Águila-Obra, A. R. D., Padilla-Meléndez, A., \& Al-dweeri, R. M. (2013). The influence of electronic service quality on loyalty in postal services: The mediating role of satisfaction. Total Quality Management \& Business Excellence, 24(9\&10), 1111-1123.

2. Chen, Y. J., \& Lei, F. F. (2017). Research on the influencing factors of customer loyalty of takeout O2O platform based on SEM. Accounting Communication, 14, 23-26+129.

3. Deng, A. M., Tao, B., \& Ma, Y. Y. (2014). Empirical study on factors influencing customer loyalty of shopping network. China Management Science, 22(6), 94-102.

4. Lam, S. Y., Shankar, V., Erramilli, M. K., \& Muthy, B. (2004). Customer value, satisfaction, loyalty, and switching costs: An illustration from a business-to-business service context. Journal of Academy of Marketing Science, 32(3), 293-311.

5. Li, Y. G. (2004). Concept comparison and marketing practice of customer satisfaction and customer loyalty. China Circulation Economy, 6, 44-47.

6. Newman, J. W., \& Werbel, R. A. (1973). Multivariate analysis of brand loyalty for major household appliances. Journal of Marketing Research, 10(4), 404-409.

7. Parasuraman, A., Zeithaml, V. A., \& Malhotra, A. (2005). E-S-QUAL: A multiple-item scale for assessing electronic service quality. Journal of Service Research: JSR, 7(3), 213-233.

8. Wang, X. Y., \& Liu, Z. (2018). Relationship among service quality, customer satisfaction and continuous use of takeout platform. Tianjin Science and Technology, 45(4), 95-99.

9. Yin, M., \& Gao, C. H. (2020). Empirical study on the impact of delivery service quality on consumer satisfaction. Logistics Technology, 43(1), 79-84.

10. Zeithaml, V. A., Parasuraman, A., \& Malhotra, A. (2000). E-Service quality: definition, dimensions and conceptual model. Marketing Science Institute, Cambridge, MA, working paper, 22.

11. Zhao, Y. N., \& Lan, C. Y. (2015). Study on the relationship between O2O service quality and customer loyalty-Taking customer satisfaction as the intermediary variable. China Price, 8, 89-91. 